DOI: 10.46340/eujem.2021.7.1.15

Oleksandr Vostriakov, PhD in Economics

ORCID ID: https://orcid.org/0000-0002-9030-6569

Kyiv National Economic University named after Vadym Hetman, Ukraine

Galyna Volokhova

ORCID ID: https://orcid.org/0000-0002-2986-6129

Kyiv National Economic University named after Vadym Hetman, Ukraine

\title{
CONCEPTUALIZATION \\ OF THE CORPORATE IDENTITY, IMAGE, AND REPUTATIONAL STUDIES
}

The present article explores the definition of corporate identity, image, and reputation, defines their conceptualization and the scope of their studies field. The main purpose of this research is to define these concepts in order to implement them in theory research and practice as a management tool for achieving strategic competitive advantage.

There is no unified definition of these concepts, and they are being studied from the different angles of management, marketing, public relations, design and psychology. This paper presents a critical analysis of researches of the existing academic output on corporate identity, image, and reputational studies, illustrates their definitions of concepts and existing classifications and vision of their interrelations from the multidisciplinary approach.

Defining corporate identity as a set of attributes that distinguish a company, we argue that image characterizes the set of associations created from a perception of these attributes by stakeholders, and reputation is a judgment about the company, based on perceptions' accumulation and formed over time.

In the present paper, we consider corporate identity, image and reputation as elements of corporate intangible assets that not only affect the perception of the company, but also has an improvement of economic performance, competitiveness and market position as consequence. We argue that the study of the nature of reciprocal interrelations between them plays an important role in diagnosing and correcting strategy in managing corporate philosophy, communications, culture, and behaviour.

Considering the peculiarities of defining the boundaries of the studied fields, in order to facilitate their perception, a schematic visualization of the model of studies interrelations was presented, which can be useful for both theoretical and practical implementation.

Keywords: corporate identity; image; reputation; identification; strategic management; behavioral studies; intangible assets.

Introduction. The topic of this article is relevant due to the impact of image and reputation on the competitiveness of the company. As a result, their improvement and refinement becomes one of the key tasks of business management, aiming at improvement of its economic performance and strengthening of its market position.

Both academics and practitioners have recently increased their interest in the relationship between corporate identity, image and reputation as part of intangible assets of an enterprise. Due to the strategic context of this study, its purpose also lays in providing theoretical basis for diagnosing of the company's strategy, as well as relationship between the company's mission, vision and values and the concepts, presented to eliminate the dissonance between them.

Strategic management of the company among depends on successful combination of tangible capabilities and capacity with intangible assets of the business, in order to maximize company's capabilities. Therefore, improving the understanding of the presented concepts is aimed at improving their management methods, which will increase the value of intangible assets and strengthen competitive advantage of a company. 
The purpose of this article is to conceptualize and differentiate corporate identity, image and reputational studies, which will improve the understanding of their relationship and areas of influence, and thus allow for diagnosis, correction and improvement of development and management of business strategy.

In past years, the understanding of corporate identity has gradually changed and now it indicates how the company's identity is manifested through behaviour, communication and symbolism, directed at the company's internal and external stakeholders ${ }^{1}$. Experts define that corporate identity refers to the unique characteristics of the company, the roots of which are associated with the behaviour of members and managers.

Researchers such as Abratt R., Ashfort B.E., Balmer J.M.T., Brown T.J., Csordás T., Gioia D., Greyser, S.A., Karaosmanoglu E., Melewar T.C., Hatch, M.J., Sahaidak M.P., Schultz, M., Wilkins, S., etc. have paid attention to the study of corporate identity and its connection with image and reputation in their research.

The gap in the interpretation of the relationship between the concepts of identity, image and reputation is significant and is supported by the uncertainty of the definition. Different schools of thought attribute the same characteristics to each of the concepts, substituting their interpretation and making them synonymous ${ }^{2}$. However, on closer research, they cannot be called synonyms, as each concept has its own field, scope, time and operating conditions that should complement each other to create more successful communications of stakeholder companies, and as a result, provide competitive advantage.

Literature review. In the modern scientific literature, there are differences in the interpretation of the concepts of image and reputation. This is due to different approaches to determining the subject's affiliation to various fields of studies such as marketing, management, public relations and psychology.

Organizational identity professionals ${ }^{34}$ generally agree to use the term "identity" to refer to the internal representation of the members of the organization, and the terms "image" or "reputation" to define the perception of external stakeholders.

J.M.T. Balmer ${ }^{5}$ notes that the word "image" comes from the Latin, and means "imitation". He is critical of most marketing authors, including P. Kotler, who relate to image in terms of a set of impressions beliefs and ideas about the organization.

There is no single approach to the definition of the term in Eastern European literature as well. From the point of view of T. Primak ${ }^{6}$, the company's image is the result of a complex influence of many factors, but, first of all, it's an issue of marketing communications.

M. Sahaidak ${ }^{7}$, defines the image as a properly formed, audiovisually reinforced, perceived and perceived by society at the associative level of the image of the organization (person, services and goods etc.), which affects its success and competitiveness. According to the author, the system of comprehensive assessment of the corporate image includes such indicators as: image of consumers of goods; product image; organizational culture; organizational socio-psychological climate; corporate internal image; corporate top-managers image; corporate employees image; corporate visual image; organizational social image; corporate business image; rating of the organization`s information impact on the public through the media (aka corporate communications). However, in this paper we argue that these indicators are structural elements of corporate identity.

The concept of "identity" comes from the Latin, and means "sameness", is a polysemic scientific and life term that is widespread in modern social sciences. In the organizational context, identity can be understood as a set of attributes of the company - the characteristic of unique corporate features, expressed in its communications, symbolism and behaviour, which are derived from the core values of the organization ${ }^{8}$.

\footnotetext{
${ }^{1}$ Money, K., Rose, S., Hillenbrand, C. (2010). "The impact of the corporate identity mix on corporate reputation". Journal of Brand Management, 18, 197-211.

${ }^{2}$ Wilkins, S., Huisman, J. (2014). “Corporate images' impact on consumers' product choices: The case of multinational foreign subsidiaries". Journal of Business Research, 67 (10), 2224-2230.

${ }^{3}$ Hatch, M. J., Schultz, M. (2002) “The dynamics of organizational identity”. Human Relations 55, 989-1018.

${ }^{4}$ Gioia, D., Schultz, M., Corley, K. (2000). “Organizational Identity, Image, and Adaptive Instability”. The Academy of Management Review, 25 (1), 63-81.

${ }^{5}$ Balmer, J. M. T., Gray, E. R. (2000) “Corporate Identity and Corporate Communications; Creating a Competitive Advantage". Industrial and Commercial Training, 32 (7), 256-261.

${ }^{6}$ Примак, Т. О. (2006). Паблік рилейшнз у бізнесі. Київ: КНЕУ, 176.

${ }^{7}$ Сагайдак, М. П. (2013). Методичне забезпечення оцінки іміджу як складової внутрішнього маркетингу підприємства. Вісник Криворізького економічного інституту КНУ, 2, 16-22.

${ }^{8}$ Balmer, J. M. T., Greyser, S. A. (2006). "Corporate Marketing. Integrating Corporate Identity, Corporate Branding, Corporate Communications, Corporate Image and Corporate Reputation”. European Journal of Marketing, 40 (7/8), 730-741.
} 
Considering corporate identity by the multidisciplinary approach, it can be defined as a tool to ensure strategic advantages, which contributes to the formation of corporate ethos, goals and values, creates a company identity, which aims to increase enterprise competitiveness, awareness and loyalty of stakeholders ${ }^{1}$. The relations between corporate identity and corporate strategy have a dualistic nature the corporate identity creates and defines corporate strategy and appears as its integral part at the same time ${ }^{2}$.

The purpose of corporate identity is to shape and manage corporate philosophy - values, mission and vision, visual identity, external and internal corporate communications, and includes structural elements such as brand identity, corporate culture, organizational identity and identification.

In this paper, we agree with Csordás, $\mathrm{T}^{3}$, who notes that corporate identity and corporate image are not the same, but the first is related to the company's self-presentation to the public, and the second applies the public perception of the results of such presentation.

The relationship between corporate attributes, selfpresentation, image and perception is considered by academics ${ }^{4}$ according to different classifications, but the vast majority of them still have common characteristics. From the standpoint of the image studies, we can divide the definition into the following classifications: by object - brand image and corporate image; by subject - external image and internal image; by creation - spontaneous image and planned image; by time - actual image and desired image.

The Balmer, J.M.T. and Greyser, S.A. ${ }^{5}$ classification reveals more aspects of the image and forms them into the following categories: focus-of image, construed image, transmitted image and received image. However, according to the authors, the classification by subjects could also be added to this list.

According to J.M.T. Balmer ${ }^{6}$, focus image is an image created by brand associations of goods or services of same category, meaning it can be considered as an image of the industry, sector, market as a whole and companies in it.

An image whose subject is a transmitter (a company) is an image that is formed and transmitted by a person, brand or company, creator of goods or services (ie the direct object of the image).

Transmitted or projected image characterizes the design of their own unique created image for all groups of stakeholders. Projected image is used in synonymous combination with the concept of imagemaking as a process of creating a single desired image of a person, brand or company.

For instance, A. Starostina ${ }^{7}$ considers image as the main means of psychological influence of the advertiser on the consumer. According to M. Sahaidak ${ }^{8}$ "image" should be understood as an artificially formed portrait of the firm, entrepreneur, product, service, etc.

Csordás, T. ${ }^{9}$ added to this category the desired image - a project representation from the standpoint of the top-management. The interpretation intersects with the notion of desired identity, which is defined by the author as an image that was conceived by the owners and managers of the company, related to the Balmer's desired identity. Also, it's known as interpreted external image which refers to members' beliefs about the perception of an external audience ${ }^{10}$.

An image whose subject is a recipient (audience) is the image perceived by the company's audience, stakeholders and target audience.

\footnotetext{
${ }^{1}$ Illia, L., Schmid, E., Fishbach, I., Hangartner, R. and Rivola R. (2004). “An Issues Management Perspective on Corporate Identity: The Case of a Regulatory Agency". Corporate Reputation Review, 7 (1), 10-21.

2 Востряков, О. В., Волохова, Г. Л. (2020). Структурний підхід до визначення видів корпоративної ідентичності підприємства. Стратегія економічного розвитку Украӥни, 47, 42-56.

${ }^{3}$ Csordás, T. (2008) “Corporate identity with special regards to the human factor". Enterprise Theory and Practice, University of Miskolc.

${ }^{4}$ Markwick, N., Fill, C. (1997). “Towards a Framework for Managing Corporate Identity”. European Journal of Marketing, 31 (5/6), 396-409.

${ }^{5}$ Balmer, J. M. T., Greyser, S. A. (2003). "Revealing the Corporation: Perspectives on Identity, Image, Reputation, Corporate Branding and Corporate-Level Marketing”. London, Routledge.

${ }^{6}$ Balmer, J. M. T. (2017). “The corporate identity, total corporate communications, stakeholders' attributed identities, identifications and behaviours continuum”. European Journal of Marketing, 51 (9/10), 1472-1502.

${ }^{7}$ Старостіна, А. (2017). Український маркетинг: становлення та перспективи розвитку. Маркетинг в Україні, 100, 4-9.

${ }^{8}$ Сагайдак, М. П. (2013). Методичне забезпечення оцінки іміджу як складової внутрішнього маркетингу підприємства. Вісник Криворізького економічного інституту КНУ, 2, 16-22.

${ }^{9}$ Csordás, T. (1994). “The Identity: A Behavioural Approach”. MBA Management Project, Bradford.

${ }^{10}$ Hatch, M. J., Schultz, M. (2001). “Are the strategic stars aligned for your corporate brand?". Harvard Business Review, 79 (2). 128-135.
} 
Perceived image (received or transmitted image) defines the portrait and feelings of an individual, forms a mental picture of associations related to a person, product or service, brand or company.

L. Balabanova ${ }^{1}$ states that the image is a portrait of a product, service or enterprise, as a set of associations and impressions about them, which is formed in the minds of consumers and creates their certain attitude towards this product, service or enterprise.

Perceived image that refers to the mental picture that is formed in the audience by directly observing the activities of the organization (product, symbolism, communications, etc.). According to R. Abratt ${ }^{2}$, image is a "general impression, formed in the minds of the audience". Later he also adds to it "the sum of impressions and expectations" 3 " part.

This category is often called "image", although even experts are sometimes unable to distinguish between image created by the organization and image that is formed in the perceptions of the individual ${ }^{4}$. That is why, academics have introduced another definition of perceived image - "the one that cannot be directly controlled"5.

A synonymous definition of corporate image was introduced by Brown and Dacin and is called "corporate associations". has.

Foroudi, P. ${ }^{7}$ discusses the concept of image from the point of view of psychology and concludes that it is the result of detailed thinking. Public relations and marketing communications scholars view this from the perspective of the recipient, and they agree that it is the result of an impression of an object being formed and transmitted.

A stereotypical image that illuminates the perception of a group of stakeholders about the outstanding characteristics of a particular group of goods and services ${ }^{8}$. Stereotypical image is formed from an oral description of qualities, literary clichés, associative comparisons that exist in the imagination of the audience and are shared by a large group of people.

Also, corporate reputation defines as one of the categories ${ }^{9}$. This is the most controversial position of the classification, as the reputation of most interpretations is a unique separate important part of the associative links and should be considered as a separate independent category. Often scholars define reputation as a judgment about the organization, formed over time.

Considering the information above, corporate image refers to ideas and associations with the organization in the one particular moment of time, in contrast to corporate reputation. Accordingly, special attention should be paid to the study of this concept.

There are various theories of the origin of the term reputation, suggesting that it comes from the Latin and means "to consider or to judge" ${ }^{\text {" }}$. As mentioned earlier, many scholars use it as synonym for image.

Corporate image and reputation are mainly created as a result of corporate communications, according to Balmer, J.M.T. and Gray, E.R. ${ }^{11}$. As pointed out by the authors, the corporate image is a direct mental picture that comes to the minds of the organization's stakeholders. Corporate reputation is shaped by various

\footnotetext{
${ }^{1}$ Балабанова, Л. В. (2002). Маркетинг. ДонДУЕТ, Донецьк, 250.

2 Abratt, R. (1989). “A New Approach to Corporate Image Management Process”. Journal of Marketing Management, 5 (1), 63-76.

${ }^{3}$ Abratt, R., Mingione, M. (2017). “Corporate Identity, Strategy and Change”. Journal of Brand Management, 24 (2), 129-139.

${ }^{4}$ Brown, A. D. (2020). "Identities in Organizations: Some Concluding Thoughts". The Oxford Handbook of Identities in Organizations. Oxford: UK: Oxford University Press, 896-908.

${ }^{5}$ Markwick, N., Fill, C. (1997) “Towards a Framework for Managing Corporate Identity”. European Journal of Marketing, 31 (5/6), 396-409.

${ }^{6}$ Brown, T. J., Dacin, P. A., Pratt, M. G., Whetten, D. A. (2006). "Identity, intended image, construed image, and reputation: an interdisciplinary framework and suggested terminology". Journal of Academy of Marketing Science, 34 (2), 99-106.

${ }^{7}$ Foroudi, P. et al. (2016). "Influence of innovation capability and customer experience on reputation and loyalty". Journal of Business Research, 69(11), 4882-4889.

${ }^{8}$ Ind, N. (1997). “The Corporate Brand”. London, MacMillan Press.

${ }^{9}$ Csordás, T. (2008). "Corporate identity with special regards to the human factor". Enterprise Theory and Practice, University of Miskolc.

${ }^{10}$ Bernstein, D. (2003). “Corporate Branding - back to basics”. European Journal of Marketing, 37 (7/8), $1133-1141$.

${ }^{11}$ Balmer, J. M. T., Gray, E. R. (2000). "Corporate Identity and Corporate Communications; Creating a Competitive Advantage". Industrial and Commercial Training, 32 (7), 256-261.
} 
factors and arises in the minds of stakeholders over time, when the amount of image leads to a clear set of expectations about the organization in terms of what it does, how it behaves, how it communicates and what it requires. The authors also argue that the sources of information may also be different.

Melewar, T.C. and Karaosmanoglu, E. ${ }^{1}$ define reputation as "a set of indicators attributed to a firm, a consequence of inference about the firm's past actions". Gioia D. ${ }^{2}$ further suggest a distinction between temporary impressions of an organization that are left to stakeholders as a result of individual actions and an organization's reputation as a relatively stable, long-term collective judgment of the audience.

Experience is also part of the conceptual model of reputation by Wood E. ${ }^{3}$ the assertion that reputation can be established or changed by communicating with reality. According to him, this is why public relations professionals prefer reputation to image.

Thus, we can conclude that corporate reputation, although often used as a synonym for image, differs from it in that it is not a perception of the current image, but is formed over a longer period of time.

In this regard, in the present paper, we considered it necessary to explore the nature of the corporate identity, image and reputation through analysing the information collected by the desk research method, investigate their interaction and create the model of the relationship between them.

Results and discussions. From the standpoint of a multidisciplinary approach, corporate identity can be defined as a tool to ensure the connection between the philosophy and behaviour of the company. However, scholars usually determine corporate self-presentation as part of identity, while it also could be named corporate brand, and call such self-presentation an image.

In this study, we propose to consider the difference between the transmitted image and the perceived image. If the elements of corporate identity are a category formed and managed by the company, ie the actions, decisions and behaviour of its members are the subject of self-presentation, they can only be a transmitted image, but cannot directly control the perception of stakeholders.

That is, for example, if a company rebrands, creates a new slogan, moves to a new office, changes communication style, creates new brands, changes management, adjusts the internal structure or even changes the mission, it is still an act of corporate identity management. Such actions cannot immediately perceive the change of the company's image in its stakeholders, change the psychological portrait of associations and perceptions in the whole audience at the same time, and, therefore, do not belong to the perceived image.

Considering the structural classification of corporate identity, according to which the concept can be divided by types rather than elements, there are three types of identity - communication, cultural and conceived, where each type can be divided into actual, desirable and ideal. According to this classification, cultural and communicative identity are elements of the transmitted image, and conceived identity should be characterized as an element of perceived image.

As perceived identity is a structural unit of corporate identity, it is a part that the organization can directly manage, can be influenced and adjusted. This conclusion is an important part of the study because the perceived identity is a type controlled by the company, and, therefore, directly affected by the company's activities ${ }^{4}$, can be objects of management, marketing and public relations, and thus may involve crisis management measures if necessary.

If we consider corporate identity as a set of attributes of a company, so as a reflection of objective reality, then the self-presentation of the company in this context should be called corporate brand (sometimes corporate brand identity). It should not be confused with brand identity, which stands for the company's brand portfolio. Corporate brand defines the company's self-presentation, ie the information that the company communicates to stakeholders as a so-called "promise of the company". A corporate brand can include positioning, communication and advertising campaigns, in general - messages that the company deliberately gives to all internal and external stakeholders, regardless of whether they reflect reality.

Corporate identity and corporate brand can also be perceived as synonyms, because even on a theoretical level it is very difficult to separate objective reality from the subjective self-presentation

\footnotetext{
${ }^{1}$ Melewar, T. C., Karaosmanoglu, E. (2006). "Seven dimensions of Corporate Identity”. European Journal of Marketing, $40(7 / 8), 846-869$.

${ }^{2}$ Gioia, D., Schultz, M., Corley, K. (2000). “Organizational Identity, Image, and Adaptive Instability”. The Academy of Management Review, 25 (1), 63-81.

${ }^{3}$ Wood, E., Somerville, I. (2016). "Public relations and corporate identity". In: Theaker, A. (ed.) (2016). The public relations handbook.

${ }^{4}$ Vostriakov, O. (2014). "Types of and methodological approaches to the development of the strategic process at the enterprise". Zarzdzanie: zeszyty naukowe politechniki czestochowskiej, 12, 42-50
} 
of a company. That is why, in this paper we do not aim to explore the conceptual difference between these concepts, and, therefore, it may be the subject of further research.

Regarding the corporate image concept, we can say that it characterizes the public perception of the results of organizational self-presentation, and stands for associations, impressions, perceptions that form a mental picture of the subject of image in the minds of stakeholders at the particular moment of time.

As mentioned earlier, image cannot be managed ${ }^{1}$, it is not under the control of the organization because its formation is influenced not only by identity, self-presentation and behaviour of the company, but also by external factors, socio-cultural behaviour of stakeholders and psychological perceptions of each individual. To simplify the definition, we can say that image differs from identity in that image is an objective expression of reality, while image is a subjective perception of such reality. However, such an interpretation cannot be considered complete and exhaustive.

Corporate image can vary depending on stakeholder groups it is perceived by ${ }^{2}$. As the simplest example, it is possible to cite the fact that often the image of a company from the position of its leader does not correspond or even contradicts the image of this company among its employees or consumers. Such dissonance can lead to following the wrong strategy formed by the manager, ignoring the opinion of employees, which will lead to their lack of motivation and unsatisfactory results, while ignoring the desires of consumers can lead to decrease in demand for products. Due to the fact that the image cannot be directly managed, organization is able to change only its identity, trying to improve its perception of the audience.

Corporate reputation can be defined as the perception of a set of features that shape the image of the organization over a long period of time. That is, reputation can be simply described as an image multiplied by time. Reputation is also characterized by variation according to stakeholder groups, determines their expectations and judgments about the company and is beyond the control of direct management.

In defining corporate identity, image and reputation, an important role should also be given to studying the concept of identification. Identification can be considered as a process of finding common features in the subjects and grouping them into one mental structure, as well as self-identification, where an individual is identifying himself with his own self ${ }^{3}$. That is, attributing certain characteristics and qualities to oneself or to subjects and determining their autonomous attributions. The study of identification can be defined as a derivative of uniformity and equivalence, as a means of formation and formation of identity of processes, phenomena and concepts.

In the present paper, we define identification as a process that affects the structural elements of corporate identity and at the same time is one of these elements, if we consider separately organizational identification as a distinct group. Further separate scientific publications will be devoted to the analysis of this question.

Conceptualization and differentiation of the studies is important for strategic management, as understanding the scope of their activities and the nature of the impact is important for improving management processes. Their interaction is a way that information passes from the word, inference, action or decision made in relation to a particular element of the structure of corporate identity to the impact of this information on its perception by individuals, and finally to transform this information unit into a solid reputation. The model of the interrelations between corporate identity, corporate image and corporate reputation is shown in Figure 1.

This model illustrates the stages that information passes from the elements of identity to the formation of a solid reputation. This approach can be used by managers and consultants in corporate strategic management, corporate communications or marketing to manage the corporate identity, as well as specialists in reputation management, to analyse and correct the corporate image. In academic sphere, the described approach can serve to define, classify and interpret the concepts of identity, image and reputation, and delineate the areas of their studies, as well as their analysis in further theoretical researches and practical implementation.

\footnotetext{
${ }^{1}$ Wąsikiewicz-Firlej, E. (2019). "Corporate identity vs. corporate image in the eyes of professionals: an interviewbased study". Scripta Neophilologica Posnaniensia, 18, 109-125.

${ }^{2}$ Melewar, T. C., Karaosmanoglu, E., Paterson, D (2005). “Corporate Identity: Concept, Components and Contribution”. Journal of General Management, 31 (1), 59-81.

${ }^{3}$ Востряков, О.В., Волохова, Г.Л. (2020). Структурний підхід до визначення видів корпоративної ідентичності підприємства. Стратегія економічного розвитку Украӥни, 47, 42-56.
} 


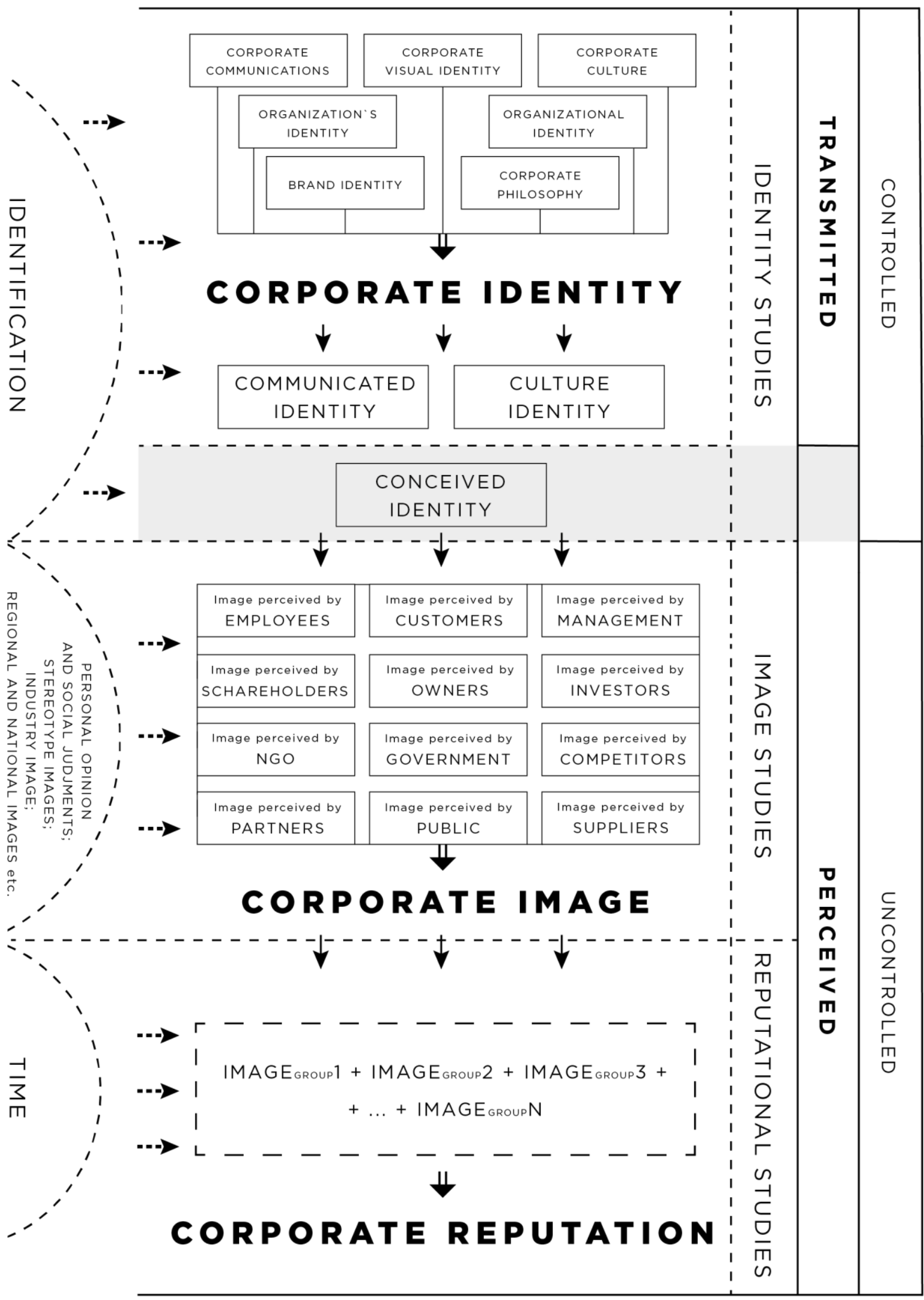

Fig. 1. Model of the interrelations between corporate identity, image and reputation

Source: developed by the authors based on their own research. 
Conclusions and future research. Uncertainty in the interpretation of the concept of corporate identity and comparison with the terms image and reputation leads to confusion in both theoretical research and practical implementation. The literature on identity, image, and reputation studies is diverse and fundamental, but not all scholars can answer the question of defining and delimiting these concepts.

According to the results of this work, we can conclude that corporate identity determines individual attributes of a company, image describes how this company is perceived by stakeholders, and reputation reflects a certain judgment about the company, formed over time.

Conceptualization of these fields of studies and delineating of their impact will help to optimize the management process of the company's intangible assets, as defining the areas of influence of each of them, and, thus, allow managers and consultants to diagnose the company's strategy, find dissonance between identity elements, as well as strengthen strategic management and improve their competitive advantage.

This paper is created as a result of theoretical research and focuses on interpretation in terms of management. And since the interpretation of concepts is influenced not only by theoretical principles, but also by paradoxes that may exist in practice, further development should be inflated by practical research on this issue. The results of further research will contribute to a greater understanding of the causal relationships and the study of the dynamics of development of these categories, and as a consequence - provide practical advice for strategic management.

As companies are influenced not only by management, but also by social, economic, and cultural factors, further research may also focus on determining the best method to analyze the impact on stakeholder perceptions and their dissonance and, consequently, the development of behavioral studies.

\section{References:}

1. Abratt, R. (1989). "A New Approach to Corporate Image Management Process". Journal of Marketing Management, 5 (1), 63-76. [in English].

2. Abratt, R., Mingione, M. (2017). “Corporate Identity, Strategy and Change”. Journal of Brand Management, 24 (2), 129-139. [in English].

3. Balabanova, L. V. (2002). Marketynh [Marketing], Donetsk: DonDUET, 250. [in Ukrainian].

4. Balmer, J. M. T., Gray, E. R. (2000). “Corporate Identity and Corporate Communications; Creating a Competitive Advantage". Industrial and Commercial Training, 32 (7), 256-261. [in English].

5. Balmer, J. M. T. (2017). "The corporate identity, total corporate communications, stakeholders' attributed identities, identifications and behaviours continuum”. European Journal of Marketing, 51 (9/10), 1472-1502. [in English].

6. Balmer, J. M. T., Greyser, S. A. (2003). "Revealing the Corporation: Perspectives on Identity, Image, Reputation, Corporate Branding and Corporate-Level Marketing”. London: Routledge. [in English].

7. Balmer, J. M. T., Greyser, S. A. (2006). “Corporate Marketing. Integrating Corporate Identity, Corporate Branding, Corporate Communications, Corporate Image and Corporate Reputation”. European Journal of Marketing, 40 (7/8), 730-741. [in English].

8. Bernstein, D. (2003). “Corporate Branding - back to basics”. European Journal of Marketing, 37 (7/8), $1133-1141$. [in English].

9. Brown, A. D. (2020). "Identities in Organizations: Some Concluding Thoughts". The Oxford Handbook of Identities in Organizations. Oxford, UK: Oxford University Press, 896-908. [in English].

10. Brown, T. J., Dacin, P. A., Pratt, M. G., Whetten, D. A. (2006). "Identity, intended image, construed image, and reputation: an interdisciplinary framework and suggested terminology". Journal of Academy of Marketing Science, 34 (2). 99-106. [in English].

11. Csordás, T. (1994). "The Identity: A Behavioural Approach”. MBA Management Project. Bradford. [in English].

12. Csordás, T. (2008). "Corporate identity with special regards to the human factor". Enterprise Theory and Practice. University of Miskolc. [in English].

13. Gioia, D., Schultz, M., Corley, K. (2000). “Organizational Identity, Image, and Adaptive Instability”. The Academy of Management Review, 25 (1), 63-81. [in English].

14. Hatch, M. J., Schultz, M. (2001). “Are the strategic stars aligned for your corporate brand?”. Harvard Business Review, 79 (2), 128-135. [in English].

15. Hatch, M. J., Schultz, M. (2002). “The dynamics of organizational identity”. Human Relations, 55, 989-1018. [in English].

16. Illia, L., Schmid, E., Fishbach, I., Hangartner, R. and Rivola R. (2004). “An Issues Management Perspective on Corporate Identity: The Case of a Regulatory Agency”. Corporate Reputation Review, 7 (1), 10-21. [in English].

17. Ind, N. (1997). “The Corporate Brand”. London, MacMillan Press. [in English].

18. Markwick, N., Fill, C. (1997). “Towards a Framework for Managing Corporate Identity”. European Journal of Marketing, 31 (5/6), 396-409. [in English]. 
19. Melewar, T. C., Karaosmanoglu, E. (2006). "Seven dimensions of Corporate Identity”. European Journal of Marketing, 40 (7/8), 846-869. [in English].

20. Melewar, T. C., Karaosmanoglu, E., Paterson, D (2005). “Corporate Identity: Concept, Components and Contribution”. Journal of General Management, 31 (1), 59-81. [in English].

21. Money, K., Rose, S., Hillenbrand, C. (2010). "The impact of the corporate identity mix on corporate reputation". Journal of Brand Management, 18, 197-211. [in English].

22. Foroudi, P., and others (2016). "Influence of innovation capability and customer experience on reputation and loyalty". Journal of Business Research, 69 (11), 4882-4889. [in English].

23. Primak, T.O. (2006). Pablik ryleyshnz u biznesi [Public relations in business]. Kyiv: KNEU. [in Ukrainian].

24. Sahaydak, M. P. (2013). Metodychne zabezpechennya otsinky imidzhu yak skladovoyi vnutrishnoho marketynhu pidpryyemstva [Methodical support of image assessment as a component of internal marketing of the enterprise]. Visnyk Kryvorijzkoho ekonomichnoho instytutu KNU, 2, 16-22. [in Ukrainian].

25. Starostina, A. (2017). Ukrayinskyi marketing: stanovlennya ta perspektyvy rozvytku [Ukrainian marketing: formation and prospects of development]. Marketing in Ukraine, 100, 4-9. [in Ukrainian].

26. Vostriakov, O. (2014). "Types of and methodological approaches to the development of the strategic process at the enterprise". Zarzdzanie: zeszyty naukowe politechniki czestochowskiej, redakcja marek szajt, 12, 42-50. [in English].

27. Vostryakov, O. V., Volokhova, G. L. (2020). Strukturnyy pidkhid do vyznachennya vydiv korporatyvnoyi identychnosti pidpryyemstva [Structural approach to the corporate identity types analysis]. Stratehiya ekonomichnoho rozvytku Ukrayiny [Strategy of Economic Development of Ukraine], 47, 42-56. [in Ukrainian].

28. Wąsikiewicz-Firlej, E. (2019). "Corporate identity vs. corporate image in the eyes of professionals: an interviewbased study". Scripta Neophilologica Posnaniensia, 18, 109-125. [in English].

29. Wilkins, S., Huisman, J. (2014). “Corporate images' impact on consumers' product choices: The case of multinational foreign subsidiaries". Journal of Business Research, 67 (10), 2224-2230. [in English].

30. Wood, E., Somerville, I. (2016). "Public relations and corporate identity". In: Theaker, A. (ed.). The public relations handbook. [in English]. 